\title{
CULT BUILDINGS ON THE MIDDLE-DON SETTLEMENTS OF THE SCYTHIAN ERA ${ }^{1}$
}

\author{
Yuriy D. Razuvaev \\ Voronezh State Pedagogical University, Voronezh, Russian Federation
}

\begin{abstract}
Introduction. As a result of many years of excavations on settlements of the Scythian era in the basin of the Middle Don the area of about 50 thousand square meters has been opened. However, buildings of the cult purpose are still not known. Methods and materials. The search for such structures is difficult due to the absence of pronounced sacral markers. However, according to publications and archival sources, structures unusual in configuration, stratigraphy and a set of accompanying materials have been selected. It was possible to identify four buildings of the $4^{\text {th }}-3^{\text {rd }}$ centuries $\mathrm{BC}$, characterized by unusual shape and layout, concentration of bonfires, ceramic and osteological materials, presence of anthropological residues. Analysis. Two buildings were located on a hillfort in the city of Semiluki, which is known for mass burials of its inhabitants. One area of about 9 square meters contained the burial of a woman and two children. In its three-part filling three hearths and sacrificial offerings, including dog bones, a female skull, fragments of ceramics, were preserved. Another 33 square meter building contained skulls and other remains of at least 13 people mixed with animal bones. Of the two buildings on the $1^{\text {st }}$ hillfort near the village of Voloshino, one area of about 100 square meters had three hearths, another seven were located around. There were found a large amount of debris of stony vessels and antique amphorae in the filling and in the layer next to this structure. Another building with an area of about 18 square meters had a hearth and a bonfire. Its filling was saturated with fragments of ceramics and animal bones. Results. The buildings in question are not similar to dwellings or household structures. They are distinguished by the unique configuration of pits and internal space, uneven and dug by pits bottom. The bonfires present in the premises were not remnants of heating devices. They, like the accompanying finds, were related to the cult activities of the local population.
\end{abstract}

Key words: Middle Don, Scythian era, settlements, cult buildings, ritual bonfires, human remains, sacrificial offerings.

Citation. Razuvaev Yu.D. Cult Buildings on the Middle-Don Settlements of the Scythian Era. Vestnik Volgogradskogo gosudarstvennogo universiteta. Seriya 4. Istoriya. Regionovedenie. Mezhdunarodnye otnosheniya [Science Journal of Volgograd State University. History. Area Studies. International Relations], 2020, vol. 25, no. 4, pp. 123-135. (in Russian). DOI: https://doi.org/10.15688/jvolsu4.2020.4.8

УДК 903.7

Дата поступления статьи: 05.01.2020

ББК 63.4(2)

Дата принятия статьи: 07.04.2020

\section{КУЛЬТОВЫЕ ПОСТРОЙКИ НА СРЕДНЕДОНСКИХ ПОСЕЛЕНИЯХ СКИФСКОЙ ЭПОХИ ${ }^{1}$}

\author{
Юрий Дмитриевич Разуваев \\ Воронежский государственный педагогический университет, г. Воронеж, Российская Федерация
}

Аннотация. В результате многолетних раскопок на поселениях скифской эпохи в бассейне Среднего Дона суммарно вскрыта площадь около 50 тыс. кв. м. Однако до сих пор не известны постройки культового назначения. Поиск таких строений затруднен ввиду отсутствия ярко выраженных сакральных маркеров. Тем не менее по публикациям и архивным источникам были отобраны сооружения, необычные по конфигурации, стратиграфии и набору сопутствующих материалов. Удалось выявить четыре постройки IV-III вв. до н.э., характеризующиеся своеобразной формой и планировкой, концентрацией кострищ, керамических и остеологических материалов, наличием антропологических остатков. Две постройки находились на Семилукском 
городище, которое известно массовыми погребениями его обитателей. Одна, площадью около 9 кв. м, содержала захоронение женщины и двух детей. В ее трехчастном заполнении сохранились три очага и жертвенные приношения, включающие кости собаки, женский череп, фрагменты керамики. Другая постройка, площадью 33 кв. м, вмещала черепа и другие останки как минимум 13 человек, перемешанные с костями животных. Из двух построек на 1-м Волошинском городище одна, площадью около 100 кв. м, имела три очага, еще семь располагались вокруг. В заполнении и в слое рядом с этим сооружением найдено большое количество обломков лепных сосудов и античных амфор. Другая постройка, площадью около 18 кв. м, имела очаг и кострище. Ее заполнение было насыщено фрагментами керамики и костями животных. Рассматриваемые постройки не похожи на жилища или хозяйственные строения. Их отличает своеобразная конфигурация котлованов и внутреннего пространства, неровное и изрытое ямами дно. Имевшиеся в помещениях кострища не являлись остатками отопительных устройств. Они, как и сопутствующие находки, были связаны с культовой деятельностью местного населения.

Ключевые слова: Среднее Подонье, скифская эпоха, поселения, культовые постройки, ритуальные кострища, человеческие останки, жертвенные приношения.

Цитирование. Разуваев Ю. Д. Культовые постройки на среднедонских поселениях скифской эпохи // Вестник Волгоградского государственного университета. Серия 4, История. Регионоведение. Международные отношения. - 2020. - Т. 25, № 4. - C. 123-135. - DOI: https://doi.org/10.15688/jvolsu4.2020.4.8

Введение. Лесостепная скифоидная культура в Среднем и отчасти Верхнем Подонье представлена многочисленными городищами и неукрепленными поселениями VIIII вв. до н.э. Около полусотни памятников уже исследованы раскопками на более-менее значительной площади, суммарно составляющей порядка 50 тыс. кв. м. В итоге получены разнообразные сведения о повседневном укладе жизни местного населения. В частности, открыто довольно много различных строений, в большинстве своем имевших жилое либо хозяйственное назначение. Заведомо в их числе должны быть и такие, что имели отношение к культово-ритуальной деятельности, которая в древности являлась основной формой общественной жизни [24, с. 16]. Однако о них практически ничего не известно.

Правда, в 1980-х гг. на верхнедонском городище, располагающемся в г. Семилуки, экспедицией Воронежского госуниверситета под руководством А.Д. Пряхина были открыты две постройки, как предполагалось, сооруженные или, по крайней мере, использовавшиеся в культовых целях [14, с. 86-89; 15, с. 1617]. Обе содержали человеческие останки и входили в число городищенских комплексов с массовыми захоронениями. Обладая обрядовыми характеристиками, семилукские погребения составляли могильник, хотя и своеобразный [18]. Впрочем, такая интерпретация не общепризнана - многие исследователи считают их случайным явлением [13, с. 145-152; 23 , с. 32-33]. Вследствие этого упомянутые постройки так и не стали источником сведений о религиозных представлениях среднедонского населения ${ }^{2}$.

В связи с этим есть смысл не только вновь обратиться к обоснованию их предназначения, но и попытаться выявить подобные сооружения на других синхронных поселениях.

Методы и материалы. Атрибуция объектов культа на бытовых памятниках задача не из легких. Она вызывает серьезные затруднения даже у специалистов по причерноморской античности [5; 9]. Исследователям поселений далекой периферии, несопоставимых по уровню развития материальной культуры, приходится еще сложнее. Не располагая ярко выраженными сакральными маркерами, они оперируют комплексом признаков, таких как местоположение, необычные форма и планировка сооружений, концентрация в них и вокруг кострищ керамических и остеологических материалов, наличие специфических находок, в частности жертвенников, антропологических остатков и др. [8; 26].

В Лесостепной Скифии известно несколько наземных и полуземляночных построек, главным отличительным признаком которых являются глиняные жертвенники [3]. Они же в сочетании со скоплениями вотивных глиняных предметов (антропо- и зооморфные фигурки, модели лепешек и зерен), а нередко и с краниологическими материалами, стали основанием для выделения на ряде поселений культовых мест или святилищ [6, с. $151-152 ; 29$, с. $184-186 ; 30$, с. $127-128]$. 
В Подонье жертвенники найдены пока лишь дважды, к сожалению вне связи с какими-либо строениями $[16, \text { с. } 78-79]^{3}$. Тем не менее в поиске культовых построек могут помочь и иные свидетельства, прежде всего это человеческие останки. Такого рода находки на лесостепных поселениях скифской эпохи трактуются по-разному [20, с. 103, 109; 22], но отнюдь не являются ординарными. Пристального внимания заслуживают своеобразная конфигурация сооружений, особенности обустройства внутреннего и внешнего пространства. Наконец, важны ассортимент, количество и распределение сопутствующих предметов, причем не только ритуального, но и бытового назначения, наверняка использовавшихся при совершении религиозных обрядов [15, с. 16; 29, с. 187].

Имея в виду названные признаки, по публикациям и архивным источникам были проанализированы те строительные комплексы среднедонских поселений, которые по своим параметрам соответствуют категории построек. По необычной конфигурации, стратиграфическим особенностям, а также по неординарным сопутствующим материалам были выделены четыре постройки, очевидно имевшие отношение к культово-ритуальной практике. Это уже упомянутые семилукские постройки и еще две, в свое время открытые руководимой П.Д. Либеровым экспедицией Института археологии на 1-м городище у с. Волошино в левобережье Тихой Сосны.

Анализ. Все четыре сооружения, судя по найденным в них вещам и керамике, существовали примерно в одно время - в IVIII вв. до н.э., однако формой, размерами и содержимым сильно разнятся. Строго говоря, к постройкам их следует причислять условно, ведь о таких конструктивных элементах, как стены и крыши, сведений нет. Тем не менее достаточно обширные и сложно обустроенные котлованы заставляют предполагать, что это были именно строения, а не просто большие ямы.

Одна из построек на Семилукском городище, размещавшаяся практически в центре площадки, была зафиксирована под номером 15 и имела площадь около 9 кв. м [14, c. 86-89]. Она представляла собой углубленный в глинистый материк котлован неправиль- но-трапециевидной формы размерами 2,9 × 2,8 м, к северо-восточному углу которого примыкала округлая ниша диаметром 1,25 м (рис. 1,1 ). Плоское дно этой ниши и всей восточной трети котлована находилось ниже уровня материка на 0,6 м. Значительная часть сооружения размерами 2,2 × 1,9 м (около 4 кв. м) была глубже на $0,08-0,15$ м, а с южной стороны углублена еще на 0,41 м за счет большой ямы. Эта яма, наполовину уходившая в подбой, сооруженный в южной и западной стенках котлована, имела в плане грушевидную форму, размеры по верху 1,85 × 1,05 м и плоское дно. Вдоль ее восточной и северной стенок, примерно на середине глубины, располагалась широкая ступенька.

В яме лежал скелет (№ 3), принадлежавший женщине 25-30 лет ${ }^{4}$. Тело умершей было размещено в западной ориентировке так, что голова размещалась на дне, а таз и согнутые в коленях ноги - на ступеньке ямы. Из-за этого верх позвоночника оказался сильно искривлен. Но в целом костяк располагался на спине с разворотом на правый бок. Согнутые в локтях руки были отведены в стороны, их кисти находились в районе живота. Берцовые кости лежали на большом камне, частично переломившись на нем.

В ту же яму, с северной стороны, был опущен верх скелета (№ 2) ребенка 11 лет, лежавшего ничком в южной ориентировке. Ноги были подогнуты в коленях и отведены вправо, а руки, согнутые в локтях почти под прямым углом, раскинуты в стороны.

$\mathrm{У}$ восточной стенки углубленной части котлована размещался еще один скелет (№ 1), принадлежавший 5-летнему ребенку, захороненному головой на северо - северо-восток. Верх костяка лежал практически ничком, но череп был повернут вправо. Правая рука согнута в локте так, что кисть оказалась возле плеча; от левой сохранилась только кость предплечья. Ноги были подогнуты в коленях, левая - сильнее, и отведены вправо.

В углубленной части котлована найдены несколько костей животных и фрагмент днища лепного горшка, а рядом со скелетами три глиняных пряслица и железное шило.

Тела женщины и детей были целенаправленно размещены в котловане вдоль стенок по кругу, хотя и в довольно небрежных позах. 
Причем с ними производились и другие манипуляции. На черепах женщины и 11-летнего ребенка, характеризующихся прижизненной искусственной деформацией, обнаружены явственные следы посмертной трепанации [28, c. 148, 151]. Детскому черепу принадлежал обработанный обломок теменной кости.

В принципе, уже после преднамеренного захоронения постройка приобрела сакральное значение. Но она стала еще и местом отправления неких заупокойных ритуалов, что было прослежено по стратиграфии заполнения (рис. 1, 3).

Над котлованом, выше уровня материка, размещался пласт гумусированного суглинка в 0,2 м толщиной, содержавший свыше 40 обломков лепных сосудов. Его подстилала тонкая прослойка глины с комочками обожженной почвы. С ней соотносится очаг 1 , располагавшийся близ западной стенки котлована.

Ниже глинистой прослойки залегал средний слой заполнения мощностью $0,25-0,30$ м. Это гумусированный суглинок с включениями золы и обожженной почвы. В нем найдены фрагменты верха крупного горшка, семь обломков других сосудов, стенка амфоры, а также многочисленные кости животных.

Под средним слоем также имелась тонкая прослойка глины, частично обожженной. На ней размещался очаг 2 , от которого осталась линза прокаленной почвы толщиной до 0,21 м. Возле него, в основном восточнее, лежали части скелета собаки (череп, нижняя челюсть и несколько других костей) и овечьи кости, а также стояла заполненная мелом придонная часть лепного горшка (рис. 1, 2). В 0,6 м южнее очага находился череп женщины, по возрасту близкой той, что была захоронена в яме на 0,8 м ниже 5 .

Третий сверху слой заполнения постройки достигал мощности 0,3 м. Это гумусированный суглинок, внизу насыщенный глиной. В нем были обнаружены 25 керамических обломков, глиняное пряслице и небольшой каменный пестик. В основании слоя, над материковым дном, впритык к западной стенке котлована располагался очаг 3.

Рассматриваемая постройка не похожа на жилище - форма ее котлована уникальна, а уступчатое дно с обширной ямой нефункционально. На уровне пола находилось очень мало бытовых остатков. В постройке отсутствовало отопительное устройство. Очаг 3 размещался чуть выше пола, практически в том же месте, что и два других, явно не предназначавшихся для обогрева помещения.

Все три очага последовательно разжигались в ритуальных целях и в процессе исполнения обрядов были засыпаны землей, включавшей красноречивые находки. Это и череп женщины, и кости собаки, и своеобразное «блюдце» с мелом. Имеется много свидетельств того, что черепные кости человека играли важную роль в культовой практике обитателей лесостепных поселений скифской эпохи [20, табл.]. Собака же являлась излюбленным жертвенным животным [1, с. 90].

Не исключено, что постройка была создана специально для погребально-жертвенного комплекса, во всяком случае не для бытовых потребностей. Как бы то ни было, данное сооружение служило местом отправления некоего культа, связанного с человеческими останками. Ритуальные действия здесь проводились в течение некоторого времени. Возможно, не слишком продолжительного, но достаточного для того, чтобы над захоронением неоднократно разжигался огонь, сооружались глинистые площадки, а также насыпался грунт с жертвенными приношениями.

Другая семилукская постройка, получившая номер 25, располагалась на удалении от первой в 30 м около края городищенского мыса и имела площадь 33 кв. м [15, с. 16-17]. От нее сохранился грушевидный в плане котлован размерами 9,5 ×6,8 м, ориентированный продольной осью по линии юго-восток - северо-запад, к которому с юга примыкала канавка размерами $4,8 \times 0,15$ м и глубиной 0,08 м (рис. 1,4$)$. Более глубокая часть котлована площадью почти 11 кв. м представляла собой своего рода приступку - удлиненно-овальную яму с плоским дном, залегавшим на 1 м ниже уровня материка. Она соединялась с расширенной частью овальных очертаний, обладавшей ступенчатым дном, углубленным на 0,2-0,9 м. Дно прорезали три округлые ямы: первая размерами $1,5 \times 1,2$ и глубиной 0,15 м, вторая $-2 \times 1,5$ м и 0,5 м, третья $1,75 \times 1,15$ м и 1,1 м.

В расширенной части котлована находились двенадцать черепов, включая фрагментированные, и отдельные кости. Остан- 
ки принадлежали как минимум тринадцати индивидам разного пола и возраста, половину из которых составляли дети ${ }^{6}$. Они лежали вперемешку с костями животных тремя скоплениями, два из которых размещались в заполнении выше дна, одно - в самой глубокой яме.

В котловане найдены многочисленные фрагменты керамики (судя по венчикам и днищам, не менее чем от 70 сосудов), четыре глиняные пряслица, железные наконечник стрелы и тесло, костяная пронизь, каменное орудие.

Данная постройка еще более специфична по конфигурации, нежели предыдущая. Она не имела отопительного устройства, зато содержала кости людей и животных в комплектации, явственно указывающей на ритуальную практику. Скорее всего, сооружение предназначалось для культа.

Одна из построек на 1-м Волошинском городище была открыта еще в 1959 г. и с тех пор неоднократно публиковалась как полуземляночное жилище $[16$, с. 47,49 , рис. $5 ; 27$, c. 169-170, рис. 6]. Она находилась в центральной части площадки и представляла собой близкий по очертаниям к овалу котлован размерами примерно $11 \times 11,6$ м (около 100 кв. м), в отдельных местах достигавший глубины от уровня материка $0,75-0,85$ м (рис. 2,1 ). С восточной стороны сооружение окаймляла возвышенная полоса материковой глины шириной 1,0-2,5 м.

Северный участок котлована площадью около 12 кв. м и глубиной 0,40-0,45 м был отделен двумя материковыми выступами в стенках, образовывавшими проход шириной 1,2 м. Основная же часть обладала неровным дном, возможно обмазанным глиной.

В котловане близ юго-восточной стенки находился овальный материковый останец площадью 3,6 м. У него были почти вертикальные стенки, кроме юго-восточной пологой, в основании которой, чуть выше дна, размещался небольшой очаг 1. Восточнее останца имелась круглая яма 1 диаметром 0,65 м и глубиной 0,15 м, а в двух метрах юго-западнее располагались такая же яма глубиной 0,25 м и еще один очаг.

Третий, более крупный очаг находился на возвышении у западной стенки котлована.
Оставшаяся от него прослойка обожженной глины с углями и золой имела размеры $1,0 \times 1,5$ м, толщину $0,35-0,40$ м и была насыщена керамикой. В полуметре северо-западнее располагалась яма 3 диаметром 1 м, имевшая ступеньки и вогнутое дно, углубленное на 0,65 м. Ее заполнение содержало угли, золу и фрагменты сосудов (некоторые склеились с теми, что лежали на очаге).

Вокруг котлована на разном удалении находилось пять ям и семь очагов (западнее, за пределами раскопа, вполне могли размещаться еще несколько). Интересно, что располагавшаяся возле очага яма 4, как и яма 3 в котловане, имела ступеньки и была насыщена золой, черепками и костями животных.

Вопреки устоявшемуся мнению данное строение нельзя причислить к жилью по ряду оснований. Такие значительные по площади постройки в регионе неизвестны - они, как правило, в 5-10 раз меньше [13, с. 79; 23, табл. 1]. Котлован имел неровное дно и материковое возвышение, что для жилищ нехарактерно. Сложно объяснить наличие в нем трех очагов. По размерам и взаиморасположению не похоже, что они способны были обогреть столь обширное помещение. В то же время выглядит необычным сосредоточение очагов вокруг постройки.

В котловане было найдено 633 обломка лепной посуды и 196 фрагментов амфор, 81 кость разных животных [10, л. 3]. Из культурного слоя над строением и с окружающей площади раскопа, составлявшей 400 кв. м, происходят еще около 4 тыс. лепных черепков, 195 амфорных стенок и свыше 2,5 тыс. костных обломков. Индивидуальных находок в самом котловане немного: два каменных оселка, абразив, четыре пряслица и фигурка животного, изготовленные из глины. Среди вещей, обнаруженных неподалеку, следует отметить бронзовый наконечник стрелы, два железных ножа, глиняную «лепешку».

Все это как будто вполне бытовой материал. Однако следует иметь в виду, что семиотический статус любой вещи в ритуальном контексте меняется [2, с. 224], а потому если не все, то многое из найденного в постройке и рядом могло применяться в культовой практике. Хорошо известно, что в скифское время (и не только) те же обломки глиня- 
ных сосудов и кости животных входили в состав поселенческих жертвенных комплексов и курганных тризн. Их концентрация в районе постройки вряд ли случайна.

Особенно это касается амфорных черепков, которых оказалось необычно много. Раскоп II, которым было исследовано сооружение, едва превысил десятую часть всей вскрытой на городище площади, но дал более 70 \% находок античной керамики. Для сравнения: другой располагавшийся неподалеку раскоп уступил ему по насыщенности лепной керамикой более чем в два раза, амфорной же - раз в 150 .

Судя по относительно большому количеству керамического импорта, 1-е Волошинское городище служило одним из важных пунктов на торговом маршруте, связывавшем Среднее Подонье с античными центрами Причерноморья [21, с. 20]. Надо думать, его обитатели охотно использовали в ритуалах привозную посуду, хотя бы и в виде обломков. К слову сказать, фрагменты круговых сосудов, наряду с лепной керамикой, широко представлены в жертвенных комплексах Боспора [25, с. 244-247].

Таким образом, и сопутствовавшие материалы дают основания полагать, что полуземлянка, расположенные рядом очаги и ямы остались от большого святилища.

Очевидно, к культово-ритуальной практике имела отношение и землянка № 2, исследованная в раскопе VII на том же городище в 1972 г. и также интерпретированная как жилище [27, с. 169 , рис. 4,3$]$. Располагаясь в центральной части площадки, на ее осевой линии, она примыкала к понижению в материке площадью 400-500 кв. м, своим видом напоминающему шестиугольник. Предполагалось, что там стояло обширное помещение, использовавшееся в «общественно-ритуальных целях» [12, c. 74]. K сожалению, доказать это невозможно, но в пределах понижения, правда на довольно значительном удалении от землянки, были найдены предметы, скорее всего, культового назначения. Это несколько глиняных фигурок и поделок [7, рис. $15,1-8]$, а также небольшой сосудик с изображением свастики [17, рис.].

Котлован землянки площадью около 18 кв. м имел в плане шестиугольную форму и своеобразно обустроенное внутреннее пространство (рис. 2, 2). По бокам его северной части находились две обширные площадки с более-менее вертикальными стенками. Они были углублены относительно уровня материка всего на 0,3-0,4 м, тогда как разделявшее их пространство достигало глубины примерно 1,8 м. От южного края котлован понижался уступами, но в месте входа, как будто просматривающегося там же, имел пологий спуск. Внизу по центру располагалась заполненная углями и золой подквадратная яма размерами 1,0 × 1,2 м, глубина которой составляла около 0,25 м. По бокам ямы, примыкая к основаниям возвышавшихся площадок, размещались два округлых отопительных устройства. Одно, имевшее глиняное основание, было определено как очаг. Его диаметр 0,9 м, толщина 0,2 м. Второе представляло собой скопление продуктов горения и было названо кострищем. Оно имело диаметр 0,8 м и толщину 0,2 м. Среди углей и золы встречались обломки сосудов и костей животных.

Черепки и кости животных находились и в заполнении котлована, распределяясь болееменее равномерно по всей его толще. Всего оттуда происходят 1110 фрагментов лепной керамики и 356 костей [11, л. 7-8, табл. 1]. Фактически это половина и четверть соответствующих находок в раскопе VII, площадь которого (214 кв. м) превысила параметры постройки почти в 12 раз. Амфоры, правда, представлены всего четырьмя обломками, еще один был найден в слое. Также в постройке найдены небольшой горшочек, девять пряслиц и конусовидное изделие из глины, а на самом верху - крупное каменное орудие типа зернотерки.

Конструктивные особенности и этого строительного котлована для жилищ абсолютно нетипичны. Заметим, что возвышенные площадки, ступенчатая южная стенка сильно сократили полезную площадь постройки, как и яма с двумя отопительными устройствами, которые к тому же выглядят совершенно избыточными для данного помещения.

Результаты. Проведенное исследование показало перспективность поиска на среднедонских поселениях построек, имевших отношение к культам. К сожалению, число памятников, исследованных на большой площади, невелико. Расширение объема раскопок неизбежно приведет к увеличению числа соответствующих объектов. И хотя пока таковых выявлено лишь четыре, стала очевидна одна из основных слож- 
ностей в их интерпретации - маловыразительность определяющих признаков.

Тем не менее уже сейчас можно утверждать, что сооружения, связанные с культово-ритуальной деятельностью, радикально отличаются по конфигурации от бытовых или хозяйственных строений. Каждое из них обладало довольно глубоким, своеобразным по форме и обустройству внутреннего пространства котлованом. Практически обязательным является наличие неровного дна, изрытого одной или несколькими ямами.

То, что это отнюдь не случайность, доказывает географически удаленная, но близкая по содержанию аналогия. На Мотронинском городище в Днепровском Правобережье открыт котлован площадью 28 кв. м, дно которого представляло собой серию уступов и ям $[4$, с. $18-$ 21]. Ямы использовались в ритуальных целях для сброса очажных отбросов и многочисленных костей животных. В заполнении котлована, состоявшем из «мусорных» отложений, на разных уровнях размещались кострища.

Кострища, очевидно, являются атрибутом культовых построек. Присутствуя в каждой, за единственным исключением, в количестве двух-трех, они явно не предназначались для отопления. Также и необычная концентрация очагов вблизи одной из построек на Волошинском городище едва ли обусловлена бытовыми или хозяйственными потребностями.

Важной характеристикой построек является наличие находок, неотличимых от обычных поселенческих, но в таком количестве или антураже, которые свидетельствуют о связи с ритуальной практикой. Сами по себе керамические черепки, кости животных, отдельные орудия труда и предметы вооружения мало что говорят о характере объекта. Однако в соответствующем контексте, то есть при наличии признаков культовой принадлежности, их информативный потенциал возрастает. Обычно такие материалы считают бытовым мусором, постепенно заполнявшим котлован руинированного строения $[4$, с. 32,39$]$. Однако и статус самого сооружения, и набор находок, и условия их залегания заставляют в этом усомниться. В частности, неясно, почему в «мусоре» оказались вполне пригодные для использования вещи и единичные черепки, а не наборы обломков разбившихся сосудов. Логичнее предположить, что отдель- ные предметы, фрагменты керамики и кости животных, возможно оставшиеся от частей туш, являлись жертвенными приношениями, попавшими в засыпку котлована в процессе исполнения религиозных ритуалов, тем более если их сопровождают кострища или разрозненные продукты горения, а также останки людей.

Исходя из того, что уже известно о поселениях скифской лесостепи, антропологические материалы могут служить одним из решающих доказательств культового назначения постройки либо использования ее для ритуальных действий. Разумеется, в зависимости от ситуации исключения возможны, но вряд ли они будут преобладать.

Нет сомнений в том, что следы сакральной жизни обитателей среднедонских поселений скифской эпохи представлены не только в постройках. Их розыск должен быть продолжен и в других строительных комплексах.

\section{ПРИМЕЧАНИЯ}

${ }^{1}$ Работа подготовлена при финансовой поддержке РФФИ в рамках проекта 18-09-00230 «Погребальные и культовые практики оседлого населения скифо-сарматской эпохи в лесостепном Подонье».

The reported study was funded by RFBR, project number 18-09-00230 “Funeral and cult practicians of settled population of Scythian-Sarmatian epoch in the Forest-steppe Don region".

2 Показательно, что в новейших монографических исследованиях региональных древностей скифской эпохи данная тема фактически не затронута [7, с. $125 ; 13$, с. 78$]$.

${ }^{3}$ Обломки глиняного жертвенника были найдены на Кировском городище при раскопках небольшого всхолмления вместе с многочисленными фрагментами керамики и костями животных, а также тремя человеческими черепами [16, с. 79]. Похоже, в том месте существовало наземное строение культового назначения, но явственных следов от него не осталось.

4 Уточненные Е.А. Шепель половозрастные определения останков из этого погребения, получившего номер 7, отличаются от публиковавшихся ранее [28, табл. 1].

5 Это далеко не единственный на городище случай подхоронения черепа в коллективное погребение (см., например: [19]).

${ }^{6}$ Антропологические материалы из этого комплекса, зафиксированного как погребение 13, исследованы М.В. Добровольской. 


\section{АРХЕОЛОГИЯ РАННЕГО ЖЕЛЕЗНОГО ВЕКА}

\section{ПРИЛОЖЕНИЕ}

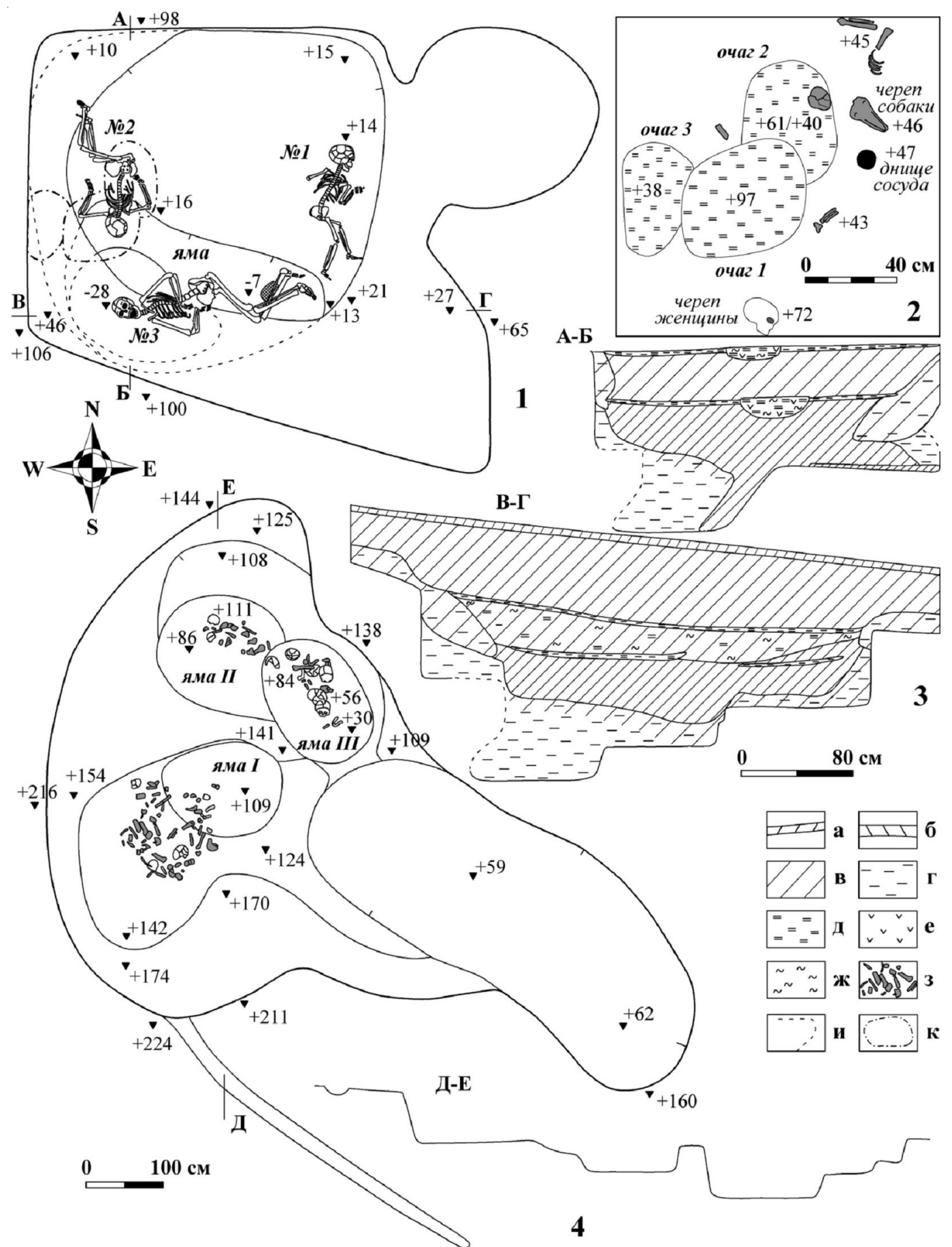

Рис. 1. Семилукское городище:

1,3 - план и профили постройки 15; 2 - очаги и культовые остатки в заполнении; 4 - план и разрез постройки 25.

Условные обозначения к рис. 1 и $2: a$ - дерн; $\sigma$ - пахотный слой; в - гумусированный суглинок; 2 - глина;

$\partial$ - обожженная почва; $e$ - уголь; ж- зола; $з$ - кости животных; $u$ - контур подбоя; $\kappa$ - очаг в заполнении

Fig. 1. Semiluksky hillfort:

1,3 - plan and profiles of building 15;2 - hearths and cult residues in the filling; 4 - plan and section of building 25. Symbols for Fig. 1 and 2: $a$ - turf; $\sigma$ - arable layer; $в$ - humused loam; 2 - clay;

$\partial$ - burnt soil; $e$ - coal; $ж$ - ash; 3 - animal bones; $u$ - contour of breakage; $\kappa$ - hearth in the filling 
Ю.Д. Разуваев. Культовые постройки на среднедонских поселениях скифской эпохи

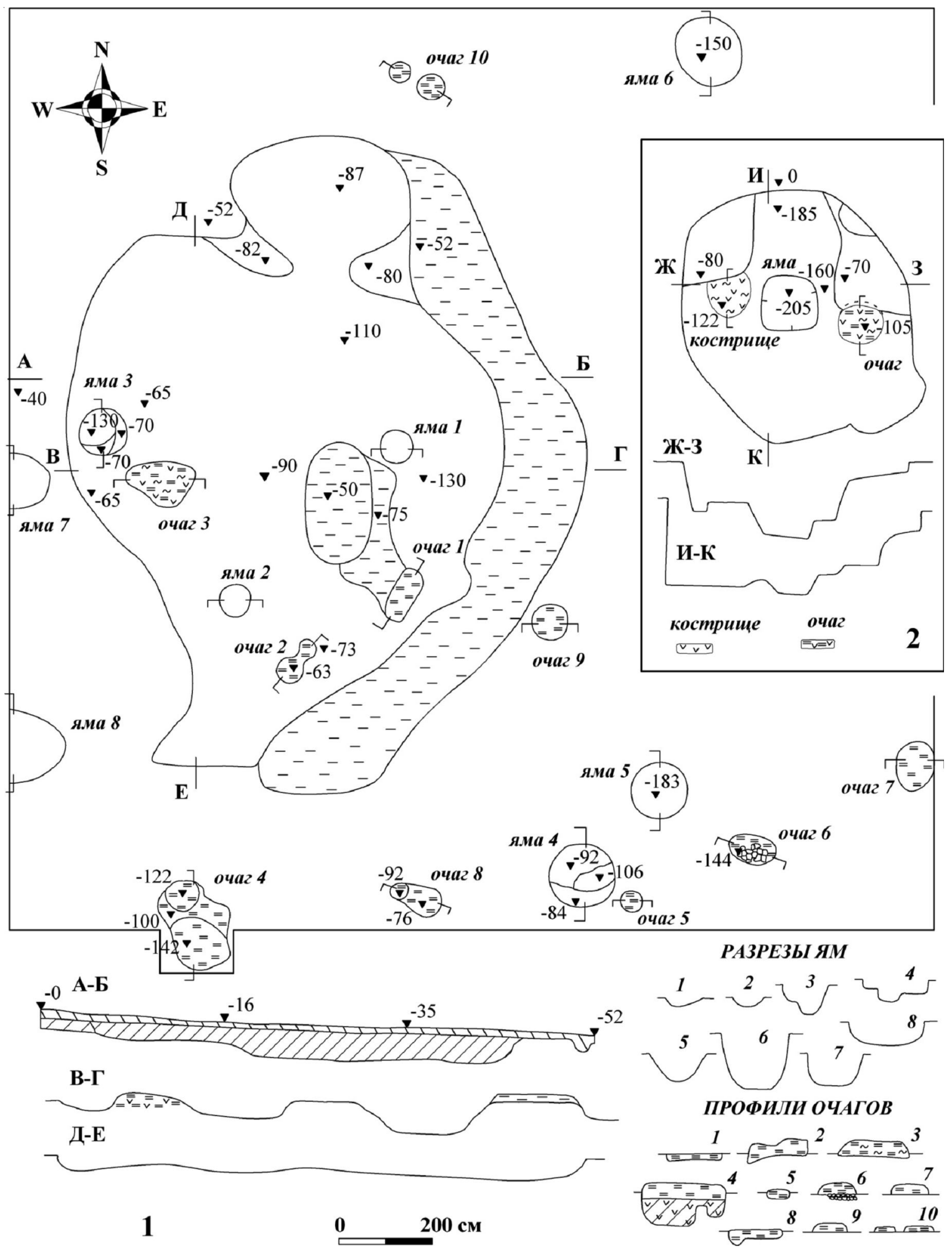

Рис. 2. 1-е Волошинское городище:

1 - план, профили и разрезы землянки, ям и очагов в раскопе II;

2 - план, разрезы и профили землянки 2 в раскопе VII

Fig. 2. $1^{\text {st }}$ Voloshinsky hillfort:

1 - plan, profiles and sections of the dugout, pits and hearths in excavation trench II;

2 - plan, sections and profiles of dugout 2 in excavation trench VII 


\section{СПИСОК ЛИТЕРАТУРЫ}

1. Андріенко, В. П. Основні культові обряди та споруди у племен лісостеповоі Скифіi / В. П. Андріенко // Вісник Харьківського університету. - 1974. - № 104. - Вип. 8. - С. 89-96.

2. Байбурин, А. К. Семиотический статус вещей и мифология / А. К. Байбурин // Материальная культура и мифология / отв. ред. Б. Н. Путилов. Л. : Наука, 1981. - С. 215-226. - (Сборник Музея антропологии и этнографии ; вып. XXXVII).

3. Безсонова, С. С. Глиняні жертовники лісостепового Подніпров'я ранньоскіфського часу / С. С. Безсонова // Археологія. - 1996. -№4. - С. 25-40.

4. Бессонова, С. С. Мотронинское городище скифской эпохи (по материалам раскопок 19881996 гг.) / С. С. Бессонова, С. А. Скорый. - Киев ; Краков : ИА НАНУ, 2001. - 242 с.

5. Бутягин, А. М. Факторы выделения античных святилищ VI-IV вв. до н.э. (по материалам боспорских городов) / А. М. Бутягин, Д. Е. Чистов // Святилища: археология ритуала и вопросы семантики : материалы тематической научной конференции / отв. ред. Д. Г. Савинов. - СПб. : Изд-во С.-Петерб. ун-та, 2000.- С. 62-67.

6. Гавриш, П. Я. Племена скіфського часу в лісостепу Дніпровського Лівобережжя (за матеріалами Припсілля) / П. Я. Гавриш. - Полтава : Археологія, 2000. - 232 с.

7. Гуляев, В. И. На восточных рубежах Скифии (древности донских скифов) / В. И. Гуляев. М. : ИА РАН, 2010. - 344 c.

8. Ефремова, Н. С. Культовые комплексы Северной Азии: производственные, поселенческие, погребальные / Н. С. Ефремова // Уральский исторический вестник. - 2016. - № 4 (53). - С. 25-32.

9. Кузьмина, Ю. Н. О критериях идентификации античных святилищ / Ю. Н. Кузьмина // Российская археология. - 2011. - № 3. - С. 33-41.

10. Либеров, П. Д. Отчет о работе Воронежского отряда Лесостепной экспедиции Института археологии АН СССР в 1959 г. / П. Д. Либеров // Архив Института археологии РАН. - Ф. 1. - Р. 1.№ 1871. -88 л.

11. Либеров, П. Д. Отчет о работе Воронежской лесостепной скифской археологической экспедиции ИА АН СССР в 1972 г. / П. Д. Либеров // Архив Института археологии РАН. - Ф. 1. - Р. 1. № 4809. - 37 л.

12. Либеров, П. Д. Работы Воронежской экспедиции / П. Д. Либеров, А. И. Шкурко // Археологические открытия 1972 г. - М. : Наука, 1973. - С. 73-74.

13. Медведев, А. П. Ранний железный век лесостепного Подонья. Археология и этнокультурная история І тысячелетия до н.э. / А. П. Медведев. М. : Наука, 1999. - 160 с.
14. Пряхин, А. Д. Погребения на Семилукском городище позднескифского времени (раскопки 1986 г.) / А. Д. Пряхин, Ю. Д. Разуваев // Археологические памятники раннего железного века Окско-Донского междуречья / отв. ред. В. П. Челяпов. - Рязань : НПЦ по охране и использованию памятников истории и культуры Рязанской обл., 1993. - С. 74-94.

15. Пряхин, А. Д. Погребения на Семилукском городище позднескифского времени (раскопки 1987-1990 гг.) / А. Д. Пряхин, Ю. Д. Разуваев // Древние памятники Окского бассейна / отв. ред. В. П. Челяпов. - Рязань : НПЦ по охране и использованию памятников истории и культуры Рязанской обл., 1993. - C. 13-30.

16. Пузикова, А. И. Поселения Среднего Дона / А. И. Пузикова // Население Среднего Дона в скифское время / отв. ред. А. П. Смирнов. - М. : Наука, 1969. - С. 41-81. - (Материалы и исследования по археологии СССР ; № 151).

17. Пузикова, А. И. Работы Воронежской лесостепной экспедиции / А. И. Пузикова // Археологические открытия 1968 г. - М. : Наука, 1969. - С. 52-54.

18. Разуваев, Ю. Д. Могильник на Семилукском городище скифского времени в свете новых исследований / Ю. Д. Разуваев // Вестник Воронежского государственного университета. Серия: История. Политология. Социология. - 2015. - № 2. C. $98-107$.

19. Разуваев, Ю. Д. Новый погребальный комплекс скифского времени на Семилукском городище / Ю. Д. Разуваев // Краткие сообщения Института археологии. - 2015. - Вып. 231. - С. 157-166.

20. Разуваев, Ю. Д. Захоронения и останки людей на поселениях Лесостепной Скифии: состояние источников / Ю. Д. Разуваев // Российская археология. - 2016. - № 3. - С. 102-120.

21. Разуваев, Ю. Д. Античный керамический импорт на поселениях скифского времени в донской лесостепи: картографическое исследование / Ю. Д. Разуваев // Вестник Волгоградского государственного университета. Серия 4. История. Регионоведение. Международные отношения. 2017. - T. 22, № 2. - C. 15-24. - DOI: https://doi.org/ 10.15688/jvolsu4.2017.2.2

22. Разуваев, Ю. Д. Разрозненные человеческие останки на поселениях Лесостепной Скифии: обзор интерпретационных подходов / Ю. Д. Разуваев // Вестник Томского государственного университета. [Серия]: История. - 2018. - № 55. - С. 142147. - DOI: https://doi.org/10.17233/19988613/55/21.

23. Разуваев, Ю. Д. Семилукское городище скифского времени в археологической историографии / Ю. Д. Разуваев // Археологическое наследие. -2018 . - № 1. - С. 31-41.

24. Топоров, В. Н. О ритуале. Введение в проблематику/ В. Н. Топоров // Архаический ритуал в 
фольклорных и раннелитературных памятниках / отв. ред. Е. С. Новик. - М. : Наука, 1988. - С. 7-60.

25. Хршановский, В. А. Жертвоприношение в погребально-поминальной обрядности Европейского Боспора II в. до н.э. - IV в. н.э. (по материалам археологических раскопок некрополей Илурата и Китея) / В. А. Хршановский // Жертвоприношение: Ритуал в культуре и искусстве от древности до наших дней / отв. ред. Л. И. Акимова. - М. : Языки русской культуры, 2000. - С. 241-252.

26. Черных, Е. М. Позднеананьинское святилище на Зуевоключевском I городище (Нижнее Прикамье) / Е. М. Черных // Поволжская археология. 2013. - № 1 (3). - С. 153-167.

27. Шевченко, А. А. Жилые постройки скифского времени на территории Среднего Дона (по материалам укреплённых поселений) / А. А. Шевченко // Археологические памятники Восточной Европы / отв. ред. В. В. Килейников. Вып. 13. - Воронеж : Научная книга, 2009. - С. 163-175.

28. Шепель, Е. А. Население Семилукского городища скифского времени (по антропологическим материалам) / Е. А. Шепель // Археологические памятники Восточной Европы / отв. ред. А. Т. Синюк. Воронеж : Воронежский госпедуниверситет, 2002.C. 145-156.

29. Шрамко, Б. А. Следы земледельческого культа у лесостепных племен Северного Причерноморья в раннем железном веке / Б. А. Шрамко // Coветская археология. - 1957. - № 1. - С. 178-198.

30. Шрамко, Б. А. Бельское городище скифской эпохи (город Гелон) / Б. А. Шрамко. - Киев : Наукова думка, 1987. - 184 с.

\section{REFERENCES}

1. Andrienko V.P. Osnovni kultovi obryadi ta sporudi u plemen lisostepovoi Skifii [The Main Cult Rites and Structures at the Tribes of Forest-Steppe Scythia]. Visnik Kharkivskogo universitetu [Science Journal of the Kharkov University], 1974, no. 104, iss. 8, pp. 89-96.

2. Bayburin A.K. Semioticheskiy status veshchey i mifologiya [Semiotic Status of Things and Mythology]. Putilov B.N., ed. Materialnaya kultura $i$ mifologiya [Material Culture and Mythology]. Leningrad, Nauka Publ., 1981, pp. 215-226. (Sbornik Muzeya antropologii i etnografii [Collection of the Museum of Anthropology and Ethnography], iss. XXXVII).

3. Bezsonova S.S. Glinyani zhertovniki lisostepovogo Podniprovya rannoskifskogo chasu [Clay Sacrifices of Forest Steppe Dnieper of Early Skiphian Time]. Arkheologiya [Archeology], 1996, no. 4 , pp. 25-40.
4. Bessonova S.S., Skoryy S.A. Motroninskoe gorodishche skifskoy epokhi (po materialam raskopok 1988-1996 gg.) [Motroninskoe Fortified Settlement of the Scythian Epoch (On the Materials of Excavations in 1988-1996)]. Kiev, Krakow, IA NANU, 2001. 242 p.

5. Butyagin A.M., Chistov D.E. Faktory vydeleniya antichnykh svyatilishch VI-IV vv. do n.e. (po materialam bosporskikh gorodov) [Factors of Extraction of Antique Sanctuaries of the $6^{\text {th }}-$ $4^{\text {th }}$ Centuries BC (According to the Materials of Bosporan Cities)]. Savinov D.G., ed. Svyatilishcha: arkheologiya rituala $i$ voprosy semantiki: materialy tematicheskoy nauchnoy konferentsii [Sanctuaries: Archaeology of Ritual and Semantics Issues. Proceedings of Thematic Scientific Conference]. Saint Petersburg, Izd-vo Sankt-Peterburgskogo universiteta, 2000, pp. 62-67.

6. Gavrish P.Ya. Plemena skifskogo chasu v lisostepu Dniprovskogo Livoberezhzhya (za materialami Pripsillya) [Tribes of the Scythian Time in the Forest-Steppe Dnieper Left Bank (On the Materials of the Psel Basin)]. Poltava, Arkheologiya Publ., 2000. 232 p.

7. Gulyaev V.I. Na vostochnykh rubezhakh Skifii (drevnosti donskikh skifov) [On the Eastern Frontiers of Scythia (Antiquities of the Don Scythians)]. Moscow, IA RAN, 2010. 344 p.

8. Efremova N.S. Kultovye kompleksy Severnoy Azii: proizvodstvennye, poselencheskie, pogrebalnye [Cult Complexes of North Asia: Production, Settlement, Burial]. Uralskiy istoricheskiy vestnik [Ural Historical Journal], 2016, no. 4 (53), pp. 25-32.

9. Kuzmina Yu.N. O kriteriyakh identifikatsii antichnykh svyatilishch [On Criteria for Identification of Antique Sanctuaries]. Rossiyskaya arkheologiya [Russian Archaeology], 2011, no. 3, pp. 33-41.

10. Liberov P.D. Otchet o rabote Voronezhskogo otryada Lesostepnoy ekspeditsii Instituta arkheologii AN SSSR v $1959 \mathrm{~g}$. [Report on the Work of the Voronezh Detachment of the Forest Steppe Expedition of the Institute of Archaeology of the USSR Academy of Sciences in 1959]. Arkhiv Instituta arkheologii RAN [Archive of Institute of Archaeology of the Russian Academy of Sciences], F. 1, R. 1, no. 1871, 881.

11. Liberov P.D. Otchet o rabote Voronezhskoy lesostepnoy skifskoy arkheologicheskoy ekspeditsii IA AN SSSR v 1972 g. [Report on the Work of the Voronezh Forest Steppe Skiphian Archaeological Expedition of the USSR Academy of Sciences in 1972]. Arkhiv Instituta arkheologii RAN [Archive of Institute of Archaeology of the Russian Academy of Sciences], F. 1, R. 1, no. 4809, 371.

12. Liberov P.D., Shkurko A.I. Raboty Voronezhskoy ekspeditsii [Works of the Voronezh Expedition]. Arkheologicheskie otkrytiya $1972 \mathrm{~g}$. 
[Archaeological Discoveries of 1972]. Moscow, Nauka Publ., 1973, pp. 73-74.

13. Medvedev A.P. Ranniy zheleznyy vek lesostepnogo Podonya. Arkheologiya $i$ etnokulturnaya istoriya I tysyacheletiya do n.e. [Early Iron Age of the Forest-Steppe Don. Archaeology and Ethnocultural History of the $1^{\text {st }}$ Millennium BC]. Moscow, Nauka Publ., 1999. 160 p.

14. Pryakhin A.D., Razuvaev Yu.D. Pogrebeniya na Semilukskom gorodishche pozdneskifskogo vremeni (raskopki 1986 g.) [Burials at the Semilukskoe Fortified Settlement of the Late Scythian Time (Excavations of 1986)]. Chelyapov V.P., ed. Arkheologicheskie pamyatniki rannego zheleznogo veka Oksko-Donskogo mezhdurechya [Archaeological Sites of the Early Iron Age of the Oka-Don Interfluve]. Ryazan, NPTs po okhrane $\mathrm{i}$ ispolzovaniyu pamyatnikov istorii i kultury Ryazanskoy oblasti, 1993, pp. 74-94.

15. Pryakhin A.D., Razuvaev Yu.D. Pogrebeniya na Semilukskom gorodishche pozdneskifskogo vremeni (raskopki 1987-1990 gg.) [Burials at the Semilukskoe Fortified Settlement of the Late Scythian Time (Excavations of 1987-1990)]. Chelyapov V.P., ed. Drevnie pamyatniki Okskogo basseyna [Ancient Sites of the Oka Basin]. Ryazan, NPTs po okhrane i ispolzovaniyu pamyatnikov istorii i kultury Ryazanskoy oblasti, 1993, pp. 13-30.

16. Puzikova A.I. Poseleniya Srednego Dona [Settlements of the Middle Don]. Smirnov A.P., ed. Naselenie Srednego Dona v skifskoe vremya [Population of the Middle Don in the Scythian Time]. Moscow, Nauka Publ., 1969, p. 41-81. (Materialy i issledovaniya po arkheologii SSSR [Materials and Research on the Archaeology of the USSR], no. 151).

17. Puzikova A.I. Raboty Voronezhskoy lesostepnoy ekspeditsii [Works of the Voronezh Forest Steppe Expedition]. Arkheologicheskie otkrytiya $1968 \mathrm{~g}$. [Archaeological Discoveries of 1968]. Moscow, Nauka Publ., 1969, pp. 52-54.

18. Razuvaev Yu.D. Mogilnik na Semilukskom gorodishche skifskogo vremeni v svete novykh issledovaniy [Cemetery at the Semilukskoye Fortified Settlement of the Scythian Time in the Light of New Researches]. Vestnik Voronezhskogo gosudarstvennogo universiteta. Seriya: Istoriya. Politologiya. Sotsiologiya [Vestnik of Voronezh State University. Series: History. Political Sciences. Socilogy], 2015, no. 2, pp. 98-107.

19. Razuvaev Yu.D. Novyy pogrebalnyy kompleks skifskogo vremeni na Semilukskom gorodishche [New Burial Complex of the Scythian Time at the Semilukskoye Fortified Settlement]. Kratkie soobshcheniya Instituta arkheologii [Short Messages of Institute of Archeology], 2015, iss. 231, pp. 157-166.

20. Razuvaev Yu.D. Zakhoroneniya i ostanki lyudey na poseleniyakh Lesostepnoy Skifii: sostoyanie istochnikov [Burials and Human Remains on Habitations Sites of the Forest-Steppe Scythia: The State of Sources]. Rossiyskaya arkheologiya [Russian Archeology], 2016, no. 3, pp. 102-120.

21. Razuvaev Yu.D. Antichnyy keramicheskiy import na poseleniyakh skifskogo vremeni v donskoy lesostepi: kartograficheskoe issledovanie [Antique Ceramic Import on Settlements of Scythian Time in the Don Forest-Steppe: Cartographical Research]. Vestnik Volgogradskogo gosudarstvennogo universiteta. Seriya 4, Istoriya. Regionovedenie. Mezhdunarodnye otnosheniya [Science Journal of Volgograd State University. History. Area Studies. International Relations], 2017, vol. 22, no. 2, pp. 15-24. DOI: https:// doi.org/10.15688/jvolsu4.2017.2.2.

22. Razuvaev Yu.D. Razroznennye chelovecheskie ostanki na poseleniyakh Lesostepnoy Skifii: obzor interpretatsionnykh podkhodov [Separate Human Remains in the Settlements of Forest-Steppe Scythia: Review of Interpretative Approaches]. Vestnik Tomskogo gosudarstvennogo universiteta. [Seriya]: Istoriya [Bulletin of the Tomsk State University. History], 2018, no. 55, pp. 142-147. DOI: https://doi. org/10.17233/19988613/55/21.

23. Razuvaev Yu.D. Semilukskoe gorodishche skifskogo vremeni v arkheologicheskoy istoriografii [Semiluki Hillfort of Skiph Time in Archaeological Historiography]. Arkheologicheskoe nasledie [Archaeological Heritage], 2018, no. 1, pp.31-41.

24. Toporov V.N. O rituale. Vvedenie v problematiku [About Ritual. Introduction to the Subject]. Novik E.S., ed. Arkhaicheskiy ritual $v$ folklornykh i ranneliteraturnykh pamyatnikakh [Archaic Ritual in Folklore and Early Literary Sites]. Moscow, Nauka Publ., 1988, pp. 7-60.

25. Khrshanovskiy V.A. Zhertvoprinoshenie v pogrebalno-pominalnoy obryadnosti Evropeyskogo Bospora II v. do n.e. - IV v. n.e. (po materialam arkheologicheskikh raskopok nekropoley Ilurata i Kiteya) [Sacrificial Offering in the Funeral and Memorial Rites of the European Bosporus of the $2^{\text {nd }}$ Century BC $4^{\text {th }}$ Century AD (Based on the Materials of Archaeological Excavations of the Ilurat and Kitey Necropolises)]. Akimova L.I., ed. Zhertvoprinoshenie: Ritual v kulture $i$ iskusstve ot drevnosti do nashikh dney [Sacrifical Ritual: Meaning and Function in Art and Culture from Ancient Times till Nowdays]. Moscow, Yazyki russkoy kultury Publ., 2000, pp. 241-252.

26. Chernykh E.M. Pozdneananinskoe svyatilishche na Zuevoklyuchevskom I gorodishche (Nizhnee Prikamye) [Pozdneaninsky Sanctuary on Zuevokluchevsky I Town (Lower Prikamye)]. Povolzhskaya arkheologiya [Volga Archaeology], 2013, no. 1 (3), pp. 153-167.

27. Shevchenko A.A. Zhilye postroyki skifskogo vremeni na territorii Srednego Dona (po materialam ukreplennykh poseleniy) [Residential Buildings of the 
Skiphian Time on the Territory of the Middle Don (According to the Materials of Fortified Settlements)]. Kileynikov V.V., ed. Arkheologicheskie pamyatniki Vostochnoy Evropy [Archaeological Sites of Eastern Europe]. V.V. Kilejnikov, ed. Voronezh, Nauchnaya kniga Publ., 2009, iss. 13, pp. 163-175.

28. Shepel E.A. Naselenie Semilukskogo gorodishcha skifskogo vremeni (po antropologicheskim materialam) [Population of the Semilukskoe Fortified Settlement of the Scythian Time (On Anthropological Materials)]. Sinyuk A.T., ed. Arkheologicheskie pamyatniki Vostochnoy Evropy [Archaeological Sites of Eastern Europe]. Voronezh, Voronezhskiy gospeduniversitet, 2002, pp. 145-156.

29. Shramko B.A. Sledy zemledelcheskogo kulta u lesostepnykh plemen Severnogo Prichernomorya v rannem zheleznom veke [Traces of a Farming Cult in Forest Steppe Tribes of the Northern Black Sea Region in the Early Iron Age]. Sovetskaya arkheologiya [Soviet Archaeology], 1957, no. 1, pp. 178-198.

30. Shramko B.A. Belskoe gorodishche skifskoy epokhi (gorod Gelon) [Belskoe Fortified Settlement of the Scythian Epoch (City Gelon)]. Kiev, Naukova dumka Publ., 1987. 184 p.

\section{Information About the Author}

Yuriy D. Razuvaev, Candidate of Sciences (History), Associate Professor, Department of History of Russia, Voronezh State Pedagogical University, Lenina St, 86, 394043 Voronezh, Russian Federation, razuvaevyd@mail.ru, https://orcid.org/0000-0003-4865-3206

\section{Информация об авторе}

Юрий Дмитриевич Разуваев, кандидат исторических наук, доцент кафедры истории России, Воронежский государственный педагогический университет, ул. Ленина, 86, 394043 г. Воронеж, Российская Федерация, razuvaevyd@mail.ru, https://orcid.org/0000-0003-4865-3206 